EVALUATION OF THE RELATIONSHIP BETWEEN CREDIT DEFAULT SWAPS AND EURO AND USD EXCHANGE RATES: THE

\title{
CASE OF TURKEY
}

Turgay MÜNYAS 1

\section{ABSTRACT}

Keywords:

CDS premiums

Exchange Rate

Granger Causality Test

Credit Default Swaps

JEL CODES:

G11, G23, G32

\author{
Received Date (BaşvuruTarihi): \\ $5 / 03 / 2020$ \\ Accepted Date (Kabul Tarihi): \\ $28 / 04 / 2020$ \\ Published Date (YayınTarihi): \\ $25 / 06 / 2020$
}

The aim of this study is to evaluate the relationship between Turkey's Credit Default Swap (CDS) premiums and the USD and Euro exchange rates. In order to measure this relationship, time series analyses were used for the period January 3rd, 2005 to December 31st, 2019. Augmented Dickey-Fuller (ADF) and Phillips-Perron (PP) tests were performed for stationarity tests. Then, Johansen cointegration analysis was used to determine long-term relationships. The vector error correction model was used to determine short-term relationships, and the Granger causality test was used to determine causality directions. CDS was used as the dependent variable, and the USD and EURO exchange rates were used as the independent variables. As a result of the study, it was found that the USD rate and EURO rate variables have a long-term relationship with CDS. CDS increases by $38.8 \%$ when the USD rate increases by $1 \%$, and CDS increases by $24.2 \%$ when the Euro rate increases by $1 \%$. When we look at the coefficient values, it is seen that the effect of the USD rate on CDS is higher compared to that of the Euro rate. In addition, a bidirectional causality relationship was found between the variables.

\section{KREDİ TEMERRÜT SWAPLARI İLE EURO VE DOLAR KURLARI ARASINDAKİ ILIŞKININN DEĞERLENDİRILMESİ: TÜRKIYYE ÖRNEĞİ}

$\ddot{O Z Z}$

Anahtar Kelimeler:

CDS Primleri

Döviz Kuru

Granger Nedensellik Testi

Kredi Temerrüt Swaplarl

JEL Kodları:

G11, G23, G32
Bu çalı̧̧ada Türkiye'nin Kredi Temerrüt Swap (CDS) primleri ile Dolar ve EURO kurlar arasındaki ilişkinin ölçülmesi amaçlanmıştır. Söz konusu ilişkinin ölçülebilmesi [03.01.2005-31.12.2019] dönemi için zaman serileri analizleri ile incelenmiştir. İlk aşamada durağanlık testleri için Augmented Dickey-Fuller (ADF) ve Phillips-Perron (PP) testleri uygulanmıştır. Daha sonra uzun dönem ilişkilerin belirlenmesi için Johansen eşbütünleşme analizi kullanılmıştır. Kısa dönem ilişkilerin belirlenmesinde vector error correction model kullanılmış, nedensellik yönlerinin belirlenmesi için Granger nedensellik testi analiz edilmiştir. Bağımlı değişken olarak CDS, bağımsız değişken olarak Dolar ve EURO kurları alınmıştır. Çalışmanın sonucunda, Dolar kuru ve EURO kuru değişkenlerinin CDS ile uzun dönemli ilişkiye sahip olduğu tespit edilmiştir. Dolar kuru \%1 arttığında CDS \%38.8 artmakta, EURO kuru \%1 arttığında CDS \%24.2 artmaktadır. Katsayı değerlerine bakıldı̆̆ında, Dolar kurunun CDS üzerindeki etkisi EURO kuruna göre daha yüksek olduğu görülmektedir. Ayrica değişkenler arasında çift yönlü nedensellik ilişkisi tespit edilmiştir.

\footnotetext{
1 Dr. Öğr. Üyesi, İstanbul Okan Üniversitesi, turgay.munyas@okan.edu.tr
}

http://orcid.org/0000-0002-8558-2032

Business \& Management Studies: An International JournalVol.:8 Issue:2 Year:2020,1113-1130

Bu makale, araştırma ve yayın etiğine uygun hazırlanmış ve tithenteate intihal taramasından geçirilmiştir. 


\section{INTRODUCTION}

CDS, i.e. Credit Default Swap, is an indicator that explains country risks. In the simplest terms, if you cannot get your debt back, you ask the guarantor for it. The guarantor will vouch for you for a fee (CDS premium), and the guarantor will pay you the amount of the nonpayment. The less likely you are to receive your debt from the lender, the higher the amount of money (CDS premium) you need to pay to convince the guarantor. This means that you insure your claim (with a CDS premium) and eliminate the nonpayment risk of your claim. In summary, CDS premium is a kind of insurance premium in cases where it is risky to get back the principal and interest at the end of maturity in your bonds, etc. investments. Moreover, the higher the CDS premium, the higher the risk of nonpayment of the loan on its term.

In the simplest terms, it is a price taken from investors against the risk of nonpayment of the debt instruments (treasury bills, government bonds, financing bills, etc.) issued by a government or a country's companies on the market, on due dates. It would not be wrong to think of it as a kind of insurance. This insurance premium paid against the risk of nonpayment is called the CDS premium.

The government and private sector companies borrow money from people, companies or some sectors for many reasons, such as providing cash balance, repaying a previous debt, intervening in the exchange rate in the market or for investment, both in the long and short term. In exchange for this borrowed money, some bonds are issued depending on the maturity of the debt. Especially when the debt is due, the investor wants to receive both the debt and its committed interest in full. Thus, at this point, the debt is guaranteed to be paid through a premium, considered a kind of insurance, in order to avoid the concern that may arise because of the question "What if the debtor fails to pay back?" This premium, which is a type of insurance premium, is called the CDS premium.

CDS operations are defined by four basic parameters: These are;

- $\quad$ Credit Factor: The CDS contracts are indexed to the credit risk of the transacted financial asset (bond or credit). 
- $\quad$ Nominal Quantity: Indicates the amount of credit risk transferred from one party (creditor) to the other (third party).

- $\quad$ Spread (Risk Premium): They are periodic premium payments. In practice it is usually paid every 6 months.

- Maturity: Refers to the expiration date of the CDS contract (Erdil, 2008, 78).

CDS premium is an indicator that measures the countries' risks of not paying back their debts. Therefore, the higher the premium, the country enters a more risky environment unfortunately.

In addition to returns such as interest, the investor will also face a cost such as CDS premium when investing. Naturally the real and nominal return will also decrease. This additional cost will be even more costly in case the CDS score increases. In other words, when investing, the investor will take risks and also bear a surplus monetary cost. This would further increase the risk of finding debt for the state and the private sector.

In line with the decline of confidence in credit rating agencies with the global economic crisis of 2008, a need for new indicators has emerged in order to accurately and timely analyze the risk for economic agents in the market. As a result of this need, the indicators and instruments that can replace the credit rating have become of great importance for the relevant economic agents. CDS has been one of the indicators that international investors use very often for evaluating their investment risks simultaneously in foreign countries, especially after the 2008 global economic crisis. As in all over the world, CDSs are affected by economic and political factors in Turkey. After the 2008 global economic crisis, CDS began to serve as a barometer of the economy.

Studies investigating Turkey's risk perception in the literature generally focus on the relationship between country credit rating and CDS, and macroeconomic variables, financial variables and country CDS premiums. In this study, the relationship between Turkey's Credit Default Swaps and Dollar and Euro exchange 
rates [03.01.2005-31.12.2019] was analyzed with the time series analysis for 5 days of the week.

\section{LITERATURE}

In the literature review, it is observed that the studies are generally aimed at investigating Credit Risk Swaps. The studies on Credit Risk swaps in the literature are as follows.

In his 2019 study, Fettahoğlu investigated whether there was a relationship between CDS premiums and the risk appetite index. The analysis was performed using 5-year CDS premiums covering the period between November 1st, 2013 and February 9th, 2018. As a result of the study, he found that CDS premiums drop as investors' risk appetite increases.

In 2018, Akkuş et al. investigated whether there was a volatility spread effect between bonds and CDS premiums, and the relationship between these two financial products. The analysis of the study was carried out using 5-year CDS and 5-year benchmark bond interest rate return data of Turkey for the period March 19th, 2012 to October $24^{\text {th }}, 2017$. As a result of their study, Akkuş et al. found that there was a high positive correlation between the interest rates of 5-year government bonds and CDS risk premiums in Turkey.

In their study conducted in 2018, Dinç, Y1ldız and Kırca aimed to identify the structural breaks in CDSs calculated for Turkey and the economic and political reasons behind these breaks. The analysis was performed on the basis of monthly CDS data, covering a 5-year-period from January 2012 to December 2016. As a result of their study, Dinç et al. found that there were four separate structural breaks in Turkey's CDS premiums during the analysis period. They found that these breaks were downwards in April 2013, and upwards in September 2014, June 2015 and February 2016, respectively. When they looked at the reasons for the structural breaks in the relevant periods, they saw a large number of economic and political events in these periods, and concluded that these events had an effect on the breaks in the CDSs.

In their 2018 study, Yenisu and Yenice investigated the effect of countries' key 
macroeconomic variables on the country risk. The analysis of their study was carried out using monthly data from the period June 2008 - April 2018. As a result of the study, they found that there is a long-term relationship between the exchange rate and interest rates and CDS, and that there is a one-way causality relationship from exchange rate and interest rates towards CDS. They found that there was no cointegration and causality relationship between the inflation rate and the CDS.

Danac1 et al. investigated whether there was a relationship between CDS premiums and growth in Turkey in 2017. The analysis was carried out using the CDS premiums and growth figures of Turkey between 2009 and 2015. As a result of their study, they found a bidirectional causality relationship between economic growth and CDS variables.

In their study in 2017, Bektur and Malcıoğlu investigated the relationship between Turkey's Credit Default Swap (CDS) premiums and stock market closing indices (BIST 100). The analysis of their study was carried out using daily data between October 12th 2000 and February 17th, 2017 . As a result of their study, they found a one-way relationship between the BIST 100 Index and CDS premiums from CDS to the stock exchange.

Çonkar and Vergili investigated the relationship between Turkey's credit default swaps and exchange rates in 2017. They used time series analyses for the period January $4^{\text {th }}, 2010$ to December $31^{\text {st }}, 2015$ period. As a result of the study, they found that Turkey's credit default swaps and foreign exchange rates did not change together in the long-term. They also identified a one-way causality relationship from the USD towards the CDS and the Euro.

In his 2017 study, K1lc1 investigated the relationship between Turkey's 5-year CDS premiums and macroeconomic and financial variables, which are believed to lead to a change in the country's credit risk. The analysis of the study was carried out by applying Engle-Granger and Johansen Cointegration Tests, using monthly values for the 2010-2016 period and the end-of-month values of the CDS premiums with a term of 5 years within the same period. They found as a result of their study that the relationship between Turkey's 5-year CDS premiums and macroeconomic and 
financial variables was weak, and that the explanatory power of these variables was not evident.

Telek and Şit investigated whether there was a relationship between Turkey's risk premium and the total amount of non-performing loans in the Turkish banking sector in 2017. The analysis was carried out using the non-performing loans total and CDS premiums of the Turkish banking sector between 2005 and 2015. As a result of their study, Telek and Şit identified a causal relationship from CDS to Problematic Loans. They observed a drastic increase in problematic loans as risk premiums increased.

In their 2015 study, Corte, Sarno, Schmeling and Wagner investigated the relationship between the currencies of 20 countries in USD and CDSs. The analysis of their study was carried out using the data between January 2003 and November 2013. In the study, they found that there appeared to be a depreciation in the exchange rates in response to an increased credit default swap due to the country's risk.

In their study in 2014, Wang and Yao investigated financial components affecting CDS premium and volatility in 6 Latin American countries before and after Lehman's bankruptcy using a data set from August 2006 to September 2010. Their study found that while there was a significant relationship between the global risk perception fear (VIX) index and the country's risk premium prior to Lehman's bankruptcy, the relationship was not significant afterwards.

In their study in 2013, Keten et al. investigated the relationship between the 5year CDS premiums in Turkey and the financial variables that are believed to affect the CDS premium. The study used the price of Brent oil, Dow Jones Stock Market Index, U.S. short-term and long-term interest rate variables along with Turkey's 5year CDS premium. The analysis of their study was carried out using daily data between October 2000 and May 2013. As a result of their study, Keten et al. identified a long-term relationship between the variables. In addition, they identified a oneway causality relationship from U.S. long-term interest rates towards Turkey's 5-year CDS premium. 
In their 2013 study, Liu and Morley used 2004-2010 dataset of Belgium, the UK, Switzerland, Spain, France, Italy, Norway, Portugal, Ireland, the Netherlands, Germany, Japan and the United States, and investigated the relationship between 10year CDS premiums and various macroeconomic variables, including unemployment, exchange rates, stock market indices and industrial production through the method of panel analysis. As a result of their study, they identified a significant correlation between the variables and many of the countries that were the subject of the study.

In 2013, Pollege and Posch studied whether the CDS premium gave the signals needed to manage the bond portfolio. The scope of the study covers 13 European countries. The analysis of the study was carried out using the dataset of the period between May 2000 and December 2010. The study investigated the results of the investment decisions taken according to the direction of the CDS bond base between the day of the bond announcement and the day of the borrowing. As a result of the study, they found that the strategy of selling the existing bonds to buy new bonds in case of positive base was successful in 9 countries other than Finland, Ireland, Portugal and Sweden.

In their 2013 study, Vashkevich and Basazinew investigated the relationship between CDS and stock market indices by using Granger causality and VAR analysis methods using the 2007-2011 dataset of Asian countries. As a result of their study, they found that there was a negative correlation between equity markets and CDS premium of countries.

In a study by Sand in 2012, the relationship between 5-year maturity CDS premiums and macroeconomic variables, such as the current account deficit, risk-free interest rate, real exchange rate, investors' risk appetite, inflation rate and GDP, was investigated by using a 2007-2011 dataset of 16 European nations. As a result of his study, Sand found a negative relationship between countries' CDS premiums and the current account deficit, risk-free interest rate, real exchange rate and investors' risk appetite, and a positive relationship with GDP and inflation rates.

In their 2011 study, Longstaff et al. investigated the relationship between CDS 
premiums and local and global variables using a 2000-2010 monthly dataset from 26 selected countries. As a result, they found a positive relationship between exchange rates and countries' CDS premiums using the regression analysis method.

In a study conducted in 2010, Brandorf and Holmberg analyzed the relationship between CDS premiums and macroeconomic indicators in Italy, Greece, Ireland, Portugal and Spain using regression analysis. The study data covers the period March 2004 to September 2009. As a result of the study, they identified the relationship between public debt, unemployment and the inflation rate and the change in CDS premiums.

In 2010, Fontana and Scheicher investigated the relationships between CDS premiums and the risk-free interest rate, investors' perception of risk, external debt and the iTraxx index with the help of regression analysis. They carried out the analysis using weekly data from 10 countries in the Euro Zone in the period 01/200609/2008. As a result of their study, they found that the decrease in investor risk appetite caused an increase in CDS premiums.

In a study conducted by Plank in 2010, the relationship between the 5-year term CDS premiums and external debt solvency was investigated for 6 developing countries, including Turkey, Czech Republic, Russia, Poland, Romania and Hungary. In the analysis of the study, data from 6 developing countries was analyzed for the period $01 / 2001-12 / 2009$. As a result of the study, he found that there was a high correlation between CDS premiums and countries' external debt solvency.

In their study in 2010, Zhang, Yau and Fung investigated the relationship between CDS premiums and the foreign exchange market during the 2007-2008 crisis period. Analysis of the study was carried using the VAR model and the Granger Causality Test. As a result of the study, the CDS market was found to have a strong price leadership in the foreign exchange market.

In their study in 2009, Meng et al. investigated the spread of volatility between CDS, stock and bond markets. They used data for the period 03.03.2003-31.03.2005 for the analysis in their study. As a result of their study, Meng et al. found that volatility in any of the CDS, stock and bond markets does not widely affect the other 
two markets.

In their 2009 study, Chan, Fung and Zhang investigated the relationship between CDS premiums and stock prices in seven Asian countries. The analysis of the study was carried out using the data between January 2001 and February 2007. A strong negative correlation between CDS premiums and stock indexes was found in most of the countries studied.

In 2008, Remolona et al. investigated the relationship between CDS premiums and factors that are believed to have an impact on country risk through regression analysis. The study data cover monthly data of 24 countries from the period January 2002 to May 2006. As a result of the study, they found that the indices that show risk tolerance, such as the inflation rate, the VIX (Volatility Index) Index and Risk Appetite had an effect on risk premium and country risk.

In their 2007 study, Longstaff et al. studied the risk outlook of government bonds in order to investigate the credit risk determinants. The analysis of the study was carried out using the data of the period between November 2000 and May 2007. The study covers 26 developed and emerging economies. The results of their study showed that there was a high correlation between CDS premiums of different countries and that more than $50 \%$ of the change in credit risk premiums was explained by three basic variables. These variables include the American stock exchange and the high-yield bond market, capital flows, and global risk.

\section{ECONOMETRIC ANALYSIS}

\subsection{Representation of the Data}

In the study, the short- and long-term relationships between CDS, USD and Euro were investigated using the daily data, covering 5 days of the week, for the period January 3rd, 2005 to December 31st, 2019. The data were obtained from https://www.bloomberght.com/ and https://www.tcmb.gov.tr/ data banks. Representations of the variables are shown in Table 1 . The analyses were obtained with the help of Eviews version 10.0. The variables in the model are presented in Table 1. 
Table 1. Presentation of Variables Used in Analysis

\begin{tabular}{|l|l|l|}
\hline Variable & Representation & Definition \\
\hline USD Rate & USD & Independentvariable \\
\hline Euro Rate & EURO & Independentvariable \\
\hline CDS & CDS & Dependentvariable \\
\hline
\end{tabular}

The graphs about the course of variables over time are as follows.

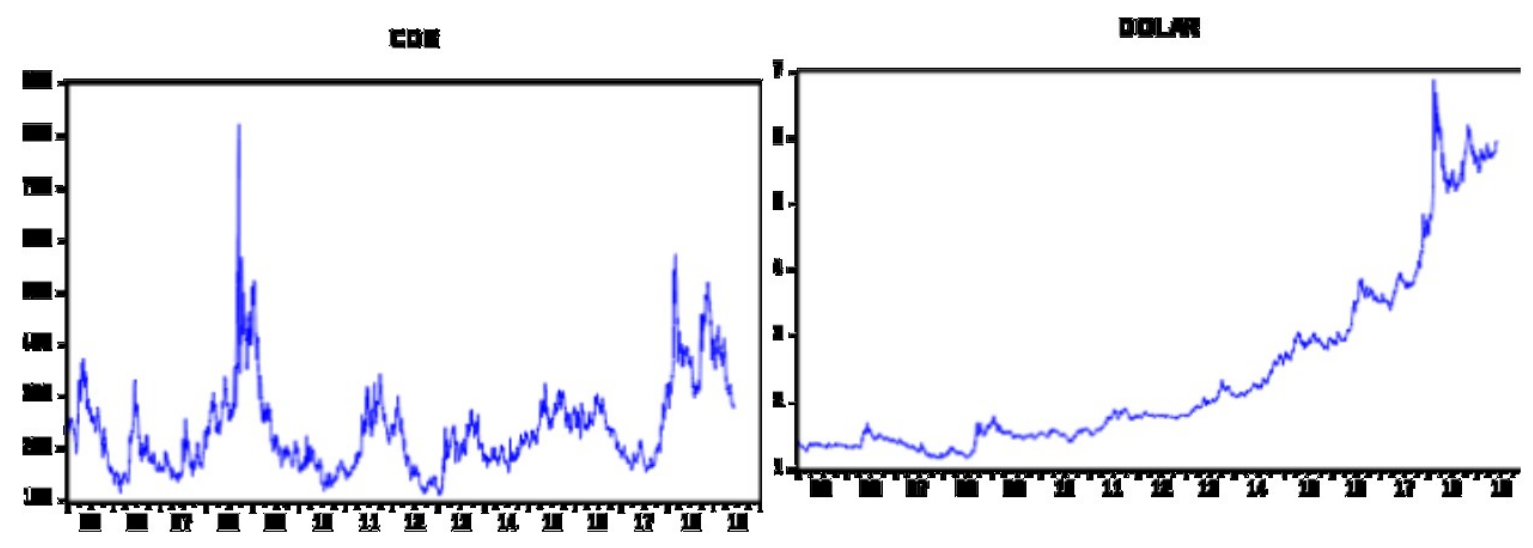

EMTo

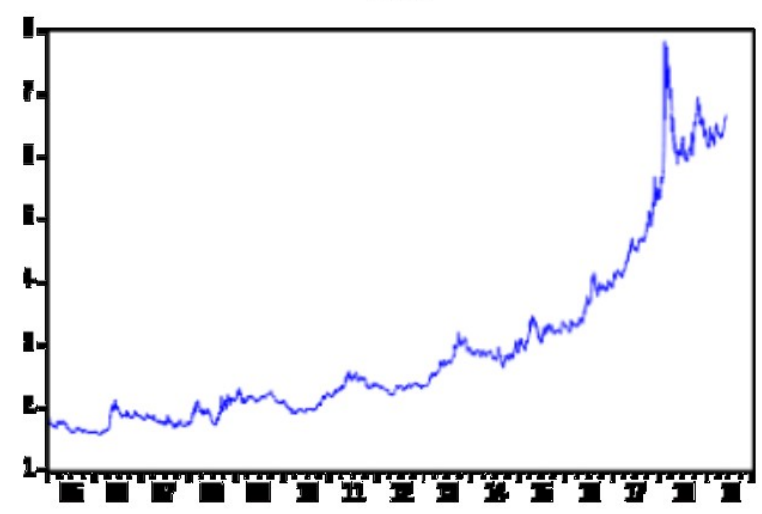

The descriptive information about the data is presented in Table 2.

Table 2. Definitions about the Data

\begin{tabular}{|l|c|c|c|}
\hline Statistics & CDS & USD & EURO \\
\hline Mean & 236.1888 & 2.392247 & 2.926888 \\
\hline Median & 216.0000 & 1.800000 & 2.350000 \\
\hline Maximum & 824.6000 & 6.890000 & 7.850000 \\
\hline
\end{tabular}




\begin{tabular}{|l|c|c|c|}
\hline Minimum & 110.9000 & 1.150000 & 1.560000 \\
\hline Std. Dev. & 85.00042 & 1.333211 & 1.399101 \\
\hline
\end{tabular}

\subsection{Method}

The presence of trend and seasonal effects in time series needs to be identified by testing. If the data are affected by trend and seasonal effects, the analysis will not be reliable. Therefore, Augmented Dickey-Fuller (ADF) and Phillips-Perron (PP) stationarity tests were applied to investigate the presence of these effects. There are frequently used criteria in the literature for determining the common lag length for the variables involved in the equations. These criteria are the Final Prediction Error (FPE), Hannan-Quinn (HQ), Schwarz (SW), Likelihood Ratio (LR) and Akaike Information Criteria (AIC). All analyses are made according to how much of a lag would be ideal as a result of the information obtained in accordance with these criteria. In the second phase of the study, the lag was determined and analyses were applied to test the hypothesis of the study. The existence of a long-term relationship between the variables and whether they act in parallel in the long-term is revealed by cointegration analysis. In this study, the Johansen method of cointegration was used for testing the long-term relationship. In the next step, the existence of short-term relationships should be investigated. In this study, an error correction model was applied to identify the short-term relationships. Finally, a causality analysis was applied to determine whether the previous-period value of the variables affected the current value. The Granger causality test, commonly used in time series, was preferred for the causality analysis.

\subsection{Findings and Evaluation}

In the first phase, stationarity tests of the data were analyzed. For each test, the "stationary" and "stationary+trend" options were used. Logarithms of variables were taken to eliminate seasonality.

Table 3. ADF and PP test results regarding the variables

\begin{tabular}{|c|c|c|}
\hline Variables & ADF & PP \\
\hline
\end{tabular}




\begin{tabular}{|c|l|l|l|l|}
\hline & \multicolumn{1}{|c|}{ Stationary } & Stationary+trend & \multicolumn{1}{|c|}{ Stationary } & Stationary+trend \\
\hline $\log$ CDS & $-1.142(0.251)$ & $-1.209(0.362)$ & $-1.198(0.377)$ & $-1.215(0.398)$ \\
\hline $\log$ USD & $-0.923(0.186)$ & $-1.112(0.195)$ & $-0.951(0.263)$ & $-1.049(0.281)$ \\
\hline $\log$ EURO & $-1.099(0.289)$ & $-1.125(0.302)$ & $-1.106(0.367)$ & $-1.157(0.375)$ \\
\hline$\Delta \log$ CDS & $-8.521(0.000)^{*}$ & $-8.733(0.001)^{*}$ & $-8.993(0.000)^{*}$ & $-9.033(0.000)^{*}$ \\
\hline$\Delta \log$ USD & $-7.453(0.025)^{*}$ & $-7.981(0.002)^{*}$ & $-8.021(0.002)^{*}$ & $-8.765(0.000)^{*}$ \\
\hline$\Delta \operatorname{logEURO}$ & $-6.092(0.000)^{*}$ & $-7.032(0.000)^{*}$ & $-7.654(0.000)^{*}$ & $-8.114(0.004)^{*}$ \\
\hline
\end{tabular}

* Stationaryvariable at a level of significance of 0.05 ,

Note: The values in parentheses are the ( $p)$ values and $\Delta$ indicates a first-orderdifference.

According to the results in Table 3, all variables have unit roots. Variables were found to be stationary for the first order difference, there is stationarity at the level I(1). Lag lengths were determined for cointegration analysis.

Table 4. Criteria for Determining Lag Levels of Variables

\begin{tabular}{|c|c|c|c|c|c|c|}
\hline Lag & LogL & LR & FPE & AIC & SC & HQ \\
\hline $\mathbf{0}$ & 3824.337 & NA & $2.59 \mathrm{e}-05$ & -2.047327 & -2.042325 & -2.045548 \\
\hline $\mathbf{1}$ & 4278.509 & 907.3709 & $2.04 \mathrm{e}-05$ & -2.285834 & -2.265823 & -2.278716 \\
\hline $\mathbf{2}$ & 4345.588 & 133.9063 & $1.98 \mathrm{e}-05$ & -2.316950 & -2.281932 & -2.304493 \\
\hline $\mathbf{3}$ & 4408.858 & 126.2016 & $1.92 \mathrm{e}-05$ & -2.346026 & -2.296000 & -2.328231 \\
\hline $\mathbf{4}$ & 4423.983 & 30.14567 & $1.92 \mathrm{e}-05$ & -2.349308 & -2.284273 & -2.326174 \\
\hline $\mathbf{5}$ & 4465.358 & 82.39430 & $1.88 \mathrm{e}-05$ & -2.366653 & -2.286611 & -2.338180 \\
\hline $\mathbf{6}$ & 4495.601 & 60.17769 & $1.86 \mathrm{e}-05$ & -2.378034 & -2.282984 & -2.344223 \\
\hline $\mathbf{7}$ & 4522.541 & 53.56416 & $1.84 \mathrm{e}-05$ & -2.387646 & -2.277588 & $-2.348496^{*}$ \\
\hline $\mathbf{8}$ & 4537.499 & $\mathbf{2 9 . 7 1 4 9 5}$ & $\mathbf{1 . 8 4 e - 0 5 *}$ & $\mathbf{- 2 . 3 9 0 8 3 8 ^ { * }}$ & $\mathbf{- 2 . 2 6 5 7 7 2 *}$ & -2.346349 \\
\hline
\end{tabular}

As can be seen in Table 4, the majority criterion indicated eligibility for 8 lags. In this case, cointegration analysis is performed with first order differences of the variables and 8 lag-lengths.

Since all series are I(1), the cointegration relationship can be investigated with 
the help of Johansen method. According to the $\lambda$ trace statistic, the null hypothesis $(\mathrm{r}=0)$, which postulates that there is no cointegration relationship between variables, is rejected against the alternative hypothesis $(r>0)$ that there is a cointegration relationship between the variables. This is because the $\lambda$ trace value is greater than the critical value of $5 \%$. In this case, the existence of at least one cointegration relationship at a critical value of $5 \%$ should be accepted. The test results for the trace ( $\lambda$ trace) value and maximum eigenvalue $(\lambda \max )$ required to determine the existence of the cointegration and the number of vectors are given in Table 5.

Table 5. Johansen Cointegration Test Result

\begin{tabular}{|c|c|c|c|c|}
\hline \multicolumn{5}{|c|}{ Cointegration Test by TraceStatistic } \\
\hline Hypotheses & Eigenvalue & TraceStatistics & $5 \%$ Critical Value & Probability \\
\hline$r=0$ & 0.143 & 39.521 & 27.116 & 0.017 \\
\hline $\mathrm{r}>1$ & 0.115 & 17.557 & 15.056 & 0.000 \\
\hline \multicolumn{5}{|c|}{ Cointegration Test by Maximum EigenvalueStatistic } \\
\hline Hypotheses & Eigenvalue & $\begin{array}{c}\text { Maximum } \\
\text { EigenvalueStatis }\end{array}$ & $5 \%$ Critical Value & Probability \\
\hline $\mathrm{r}=\mathbf{0}$ & 0.143 & 37.453 & 25.669 & 0.019 \\
\hline $\mathrm{r}>\mathbf{1}$ & 0.115 & .372 & 13.451 & 0.001 \\
\hline
\end{tabular}

When Table 5 was examined, it was found that there were two cointegration vectors in the model at the 5\% level of significance since the trace statistics and maximum eigenvalue test statistical values calculated as a result of the Johansen cointegration test were greater than the critical value. The USD rate and Euro rate variables have a long-term relationship with CDS. The coefficient values of this relationship were given by normalized equation coefficients.

Table 6. Normalized Cointegration Coefficients

\begin{tabular}{|c|c|c|}
\hline FLogCDS & FLogEURO & FLogUSD \\
\hline 1.000000 & 0.242549 & 0.388760 \\
\hline & $(0.071715)$ & $(0.029177)$ \\
\hline
\end{tabular}


*Variablewith a level of significance of 0.05

As shown in Table 6, CDS increases by $38.8 \%$ when the USD rate increases by $1 \%$, and CDS increases by $24.2 \%$ when the Euro rate increases by $1 \%$. When we look at the coefficient values, it is seen that the effect of the USD rate on CDS is higher compared to that of the Euro rate.

The Vector Error Correction Model (VECM) was estimated to investigate the short-term dynamics of CDS and USD and EURO variables that move together in the long-term. The information obtained as a result of this prediction is presented in Table 7:

Table 7. Short-Term Error Correction Model Prediction Results

\begin{tabular}{|c|c|c|c|c|}
\hline DependentVariable $: \Delta \mathrm{LCDS}_{\mathrm{t}}$ & Coefficient & Stdeviation & t-statistic & Probabilityvalue \\
\hline$\Delta$ LUSD $_{\mathrm{t}}$ & 0.2603 & 0.0077 & 33.762 & $0.0000^{*}$ \\
\hline$\Delta$ LEURO $_{\mathrm{t}}$ & 0.1268 & 0.0091 & 13.876 & $0.0000^{*}$ \\
\hline $\mathrm{ECT}_{\mathrm{t}-1}$ & -0.3451 & 0.1281 & -2.6934 & $0.0000^{*}$ \\
\hline Stationary & 343 & 0.0948 & 13.537 & $0.0000^{*}$ \\
\hline \multicolumn{5}{|c|}{ Diagnostictests: $R^{2}=0.718$, Adj. $R^{2}=0.711$, F-Statistic $=39.45$, F-Statistic $(P)=0.000^{*}$, } \\
\hline \multicolumn{5}{|c|}{ Breusch-Godfrey LM Test $(p)=0.173^{*}$} \\
\hline \multicolumn{5}{|l|}{ White Test $(p)=0.135^{\star}$} \\
\hline \multicolumn{5}{|l|}{ Ramsey RESET Test $(p)=0.148^{*}$} \\
\hline \multicolumn{5}{|l|}{ JB test $(p)=0.255$} \\
\hline
\end{tabular}

Note: * denotesstatisticalsignificance at 5\% level, JB; is Jarque-Bera normality test probabilityvalue. The autocorelation and heteroscedasticityproblems in theestimateswereattempted to be correctedwiththeNewey-West method.

The error correction coefficient in Table 7 is negative and statistically significant. That is, the error correction mechanisms of the models work. In this case, $34.5 \%$ of the short-run deviations, occurred between the long-run series, disappear and the series converge again to the equilibrium value in the long-term. That is, 
short-term deviations disappear (by 34.5\% each year) and the variables converge to the equilibrium value in the long-term. The effect of a shock entering the system will disappear after $1 / 0.3451=2.89$ unit periods (days). The impact coefficients of the USD and Euro rates in the short-term are lower than in the long-term. This shows that there cannot be an immediate and a big difference in the relations in the short-term, and that the effects grow over time.

Granger causality test was applied for causality analysis of the variables.

Table 8. Granger Causality Test Results

\begin{tabular}{|l|c|c|c|}
\hline Nullhypothesis: & N & F-ist & $p$ \\
\hline FLDOLLAR does not GrangerCause FLCDS & 3733 & 4.31076 & $0.000^{*}$ \\
\hline FLCDS does not GrangerCause FLDOLLAR & & 102.763 & $0.000^{*}$ \\
\hline FLEURO does not GrangerCause FLCDS & 3733 & 4.17582 & $0.000^{*}$ \\
\hline FLCDS does not GrangerCause FLEURO & & 69.0181 & $0.000^{*}$ \\
\hline
\end{tabular}

* causalityrelationshipexists

According to Granger causality analysis, there is a bidirectional causality between variables. The USD rate is the Granger cause of CDS, and the CDS is the Granger cause of the USD rate. Likewise, the Euro rate is the Granger cause of CDS, and the CDS is the Granger cause of the Euro rate. (CDS $\leftrightarrow$ USD and CDS $\leftrightarrow$ EURO).

\section{CONCLUSION AND RECOMMENDATIONS}

In line with the global economic crisis of 2008 and the following decline of confidence in credit rating agencies, a need for new indicators has emerged in order to accurately and timely analyze the risk. CDSs have started to be of great importance for international investors for evaluating their investment risks simultaneously in foreign countries, especially after this above-mentioned need. As in all over the world, CDSs are affected by economic and political factors in Turkey. This study aims to investigate the relationship between Credit Default Swaps and the USD and Euro exchange rates. In the study, time series analyses were used for the period 03.01.2005-31.12.2019 to analyze the relationship between Turkey's Credit Default Swaps and USD and Euro exchange rates. As a result of the study, it was found that the USD rate and EURO rate variables have a long-term relationship with 
CDS. CDS increases by $38.8 \%$ when the USD rate increases by $1 \%$, and CDS increases by $24.2 \%$ when the Euro rate increases by $1 \%$. When we look at the coefficient values, it is seen that the effect of the USD rate on CDS is higher compared to that of the Euro rate. In the study, it was concluded that the upward trend in the USD and Euro rates caused an upward trend in CDS, and the downward trend in the USD and Euro rates caused a downward trend in CDS. Considering the causality relationship between variables, a bidirectional causality relationship was found between the variables. As a conclusion of this study, it has been determined that both US dollar and EURO exchange rate variables have a positive long-term correlation with CDS, as in previous studies conducted by Yenisu\&Yenisu (2018) and also by Çonkar\&Vergili (2017).

In line with the research results, it can be suggested that the increase in the USD rate and the Euro rate increases Turkey's CDS premiums. CDS Premium has become an important indicator for the economic units that will invest in USDs and Euros. In this context, it is possible to say it functions as a barometer in the economy. It is recommended that economic units that will make economic decisions should follow this indicator and follow the trend shown by this indicator, when making investment decisions. It may be suggested that investigating the relationship between the CDS premium and the bond interest rate and/or the relationship between the exchange rates and CDS premiums of developing countries such as Turkey with similar or other models would be beneficial for future studies. 


\section{REFERENCES}

Akkuş, H., T., Sakarya, Ş., and Tüzün, O., (2018), Determination of the Effects of Volatility Spread between bond interest rates and CDS Premiums (TahvilFaizleri İle CDS PrimleriArasındakiOynaklıkYayılımEtkilerininBelirlenmesi), BankacılarDergisi, Sayı 104, pp.41-54

Bektur, Ç., and Malcıŏglu, G., (2017), The Relationship between Credit Default Swaps and BIST 100 Index: An Asymmetric Causality Analysis (KrediTemerrütTakasları İle BİsT 100 EndeksiArasındakilliş̧ki: AsimetrikNedensellikAnalizi), AİBÜ SosyalBilimlerEnstitüsüDergisi, 2017, Vol:17, Year:17, Issue: 3, 17: pp. 73-83

Brandorf, C. and J. Holmberg. (2010). Determinants of Sovereign Credit Default Swap Spreads for PIIGS- A Macroeconomic Approach, Bachelor Thesis, Lund University School of Economics and Management.

Corte, P.D., Sarno, L., Schmeling, M., and Wagner, C. (2015). Exchange Rate and Sovereign Risk. [Web: https://papers.ssrn.com/sol3/papers.cfm?abstract_id=2354935 Access Date: 06.02.2020].

Çonkar, M., K., veVergili, G., (2017), The Relationship between Credit Default Swaps and Foreign Exchange Rates: An Empirical Analysis for Turkey (KrediTemerrütSwapları İle DövizKurlarıArasındakillişki: Türkiyei̇çinAmprik Bir Analiz), ÖmerHalisdemirÜniversitesi, İktisadiveİdariBilimlerFakültesiDergisi, Year: October 2017 Volume-Issue: 10(4) pp: 59-66

Danac1, M., C., Şit, M., veŞit, A., (2017), Relationship between Credit Default Swaps (CDS) and Growth Rate: The Case of Turkey (KrediTemerrütSwaplarının (CDS'lerin) BüyümeOranıylaİlişkilendirilmesi: TürkiyeÖrneği), AksarayÜniversitesiĺktisadiveİdariBilimlerFakültesiDergisi, 9 (2) pp.67-78

Dinç, M., Yıldız, Ü., and Kırca, M., (2018), Econometric Analysis of the Structural Breaks in Turkey's Credit Risk Premium (CDS) (TürkiyeKredi Risk Primindeki (Cds) YapısalKırılmalarınEkonometrikAnalizi), UiiïD-IJEAS, (Prof. Dr. Harun Terzi Özel Sayısı):181-192 ISSN 1307-9832

Erdil, T. B. (2008). Theory and Practice of Financial Derivatives and Credit Default Swaps (FinansalTürevlerveKrediTemerrütSwaplarınınTeoriveUygulamaları). Unpublished Ph.D. Thesis. İstanbul: Kadir Has ÜniversitesiSosyalBilimlerEnstitüsü.

Fettahoğlu, S., (2019), Relationship Between Credit Default Swap Premium and Risk Appetite According to Types of Investors: Evidence From Turkish Stock Exchange, MuhasebeveFinansmanDergisi, (84): 265-278

Fontana, A. and M. Scheicher. (2010). An Analysis of Euro Area Sovereign CDS, European Central Bank Working Paper Series 1271.

Fung, H. G., Sierra, G. E., Yau, J., and Zhang, G. (2008), Are the Us stock market and credit default swap market related? Evidence from the cdx indices. The Journal of Alternative Investments, 11(1), 4361.

Keten, M., Başarır, Ç., and Kılıç, Y. (2013). Investigation of Relationship between Credit Default Swaps and Macroeconomic and Financial Variables (KrediTemerrütTakası İle 
MakroekonomikveFinansalDeğişkenlerArasındakiIllişkininİncelenmesi), 17.FinansSempozyumu/2326 October 2013/Muğla, pp: 377-386.

K1lc1, E. N., (2017), The Evaluation of the Relationship between CDS premiums Country Credit Risk: The Case of Turkey (CDS PrimleriileÜlkeKrediRiskiArasındakillişkininDeğerlendirilmesi; TürkiyeÖrneği), MaliyeFinansYazıları, (108), pp.71-86

Liu , Y., and Morley, B. (2013), Sovereign Credit Ratings, the Macroeconomy and Credit Default Swap Spreads. Brussels Economic Review-Cahiers Economiques De Bruxelles, 56(3/4), s.335-348.

Longstaff, F., Pedersen, L., Pan, J., and Singleton, K. (2011), How Sovereign Is Sovereign Credit Risk? American Economic Journal: Macroeconomics. 3.2 ,s.75-103

Longstaff F.A., Pan J., H. Pedersen L. H. and Singleton K.J.(2007), “How Sovereign is Sovereign Credit Risk?", NBER Working Papers Series, https:/ / www.nber.org/papers/w13658.pdf (21/04/2020)

Meng, L., Gwilym, O. and Varas, J. (2009). Volatility Transmission Among the CDS, Equity, and Bond Markets. The Journal of Fixed Income, 18 (3), pp.33-46.

Sand, H. J. (2012), The impact of Macro-economic Variables on the Sovereign CDS Spreads of the Eurozone Countries. Master's Thesis, University of Groningen.

Plank, T. J. (2010). Do Macro-Economic Fundamentals Price Sovereign CDS Spreads of Emerging Economies? No: $10-5$

Pollege, S., and Peter N. P., (2013), "Managing and trading sovereign risk using credit derivatives and government markets." The Journal of Risk Finance. C.XIV S. 5. s.453-467.

Remolona, E. M., M. Scatigna and E. Wu. (2008). The Dynamic Pricing of Sovereign Risk in Emerging Markets: Fundamentals and Risk Aversion, The Journal of Fixed Income, 17(4), pp.57-71.

Telek, C., and Şit, A., (2017), Investigation of the Relationship between Non-performing Loans and Risk Premium in Turkey: The Period 2005-2015) (Türkiye'de Takipteki Krediler ve Risk Primi Arasındaki İlişkinin İncelenmesi: 2005-2015 Dönemi), International Journal of Disciplines Economics \& Administrative Sciences Studies Vol:3 Issue:3 pp:152-161

Vashkevich, A., and Basazinew, S. (2013), Relationship Between Sovereign Credit Default Swap And Stock Markets. Student Umeå School of Business and Economics (15), s.1-82

Wang, A.T. and Yao, C. (2014), "Risks of Latin America Sovereign Debts Before and After the Financial Crisis", Applied Economics, 46(14): 1665-1676.

Yenisu E., and Yenice S., (2018), Effect of Basic Macroeconomic Indicators on Country Risk: The Case of Turkey (TemelMakroekonomikGöstergelerinÜlkeRiskiÜzerindekiEtkisi: TürkiyeÖrneği), İşve Hayat Dergisi, Vol: 4, Issue: 8, pp.27-53

Zhang, G., Jot Y., and Hung G. F., (2010), “Do credit default swaps predict currency values?” Applied Financial Economics. S.20. s.439-458 